\title{
LÉGSZENNYEZETTSÉG VIZSGÁLATA BUDAPESTEN
}

\author{
Varga-Balogh Adrienn (D), Leelőssy Ádám (D), Mészáros Róbert \\ ELTE Meteorológiai Tanszék, 1117 Budapest, Pázmány Péter sétány 1/A \\ e-mail: vargabaloghadrienn@gmail.com, leelossyadam@gmail.com, \\ mrobi@nimbus.elte.hu
}

\section{Bevezetés}

A légszennyezettség Földünk nagy részén okoz jelentős környezeti problémát. Európa számos nagyvárosában figyelhető meg a légszennyező anyagok magas koncentrációja. Magyarországon a levegőminőség romlása leginkább a téli félévre tehető, aminek elsődleges okozója a lakossági fütés. A tavaszi és nyári időszakban általában a mezőgazdasághoz kötődő, illetve a közlekedésből származó szennyezőanyagok koncentrációja növekszik meg. A települések levegőminőségének romlása befolyásolja az életkörülményeket, illetve számtalan egészségügyi problémát okozhat, ezért fontos, hogy mérések és modellszimulációk segítségével minél pontosabb képet kapjunk a légszennyezettségi viszonyokról. Tanulmányunkban Budapest levegöminőségét elemezzük két vizsgált időszakra. A 2018-2019 fütési szezonra a Copernicus Atmosphere Monitoring Service (CAMS) modelljeinek optimalizált előrejelzéseit készítettük el, 2020 tavaszára pedig a Covid-19 megbetegedések lehetséges levegőkémiai hatásait elemeztük.

\section{Elörejelzés városi környezetben}

A légszennyezettség megfigyelését az Országos Légszennyezettségi Mérőhálózat (OLM) végzi, így rendelkezésünkre áll Magyarország számos pontján - ezen belül Budapesten 12 méröállomáson - a légszennyező anyagok koncentrációja. A budapesti méröállomások elhelyezkedése az 1. ábrán látható.

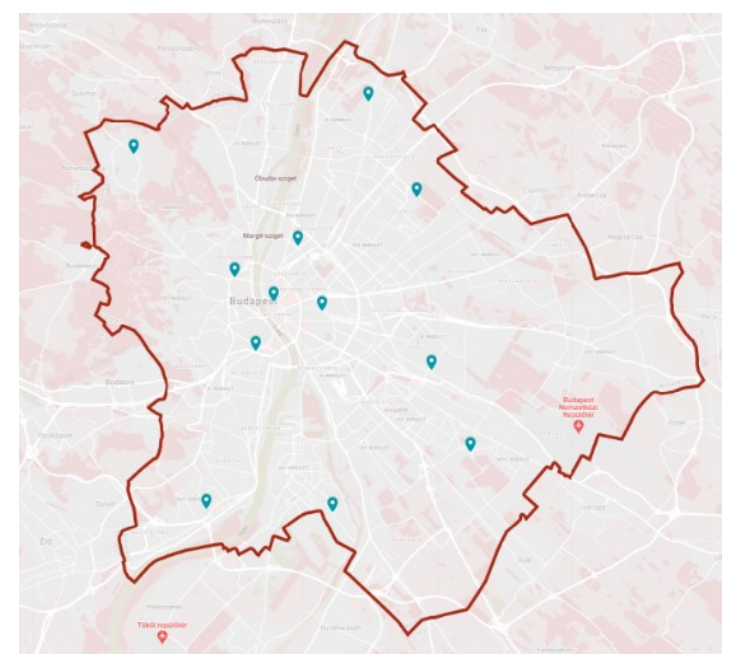

1. ábra: Az Országos Légszennyezettségi Mérőhálózat 12 budapesti mérőállomásának elhelyezkedése.

A légszennyezettség aktuális, vagy múltbeli állapotának megfigyelésén túl annak előrejelzése is fontos feladat. A szennyezőanyagok koncentrációját levegőkémiai modellek segítségével jelezhetjük előre. Ezek a modellek a rendelkezésre álló időjárás-előrejelzés mellett az emissziót, valamint a korábbi napok mérési adatait használják. Az előrejelzéseket a modellektől 
függően különböző felbontású rácson kapjuk meg. Mivel a rácsponti adatoknak egy rácscellára reprezentatívnak kell lenni, ezért a városi mérőpontok adataihoz viszonyítva gyakran jelentős hibával terhelt az előrejelzés.

Elemzéseink során a CAMS modelljeinek előrejelzéseit vizsgáltuk városi mérőállomások adataihoz viszonyítva. A CAMS rendszerében 7 , egymástól függetlenül fejlesztett európai modell levegőkémiai előrejelzései érhetők el, melyek $0,1^{\circ} \times 0,1^{\circ}$-os felbontásban adják meg a különböző légszennyezők koncentrációjának előrejelzését Európa területére. A CHIMERE, EMEP, EURAD, LOTOS-EUROS, MATCH, MOCAGE és a SILAM modellek, valamint az ezek mediánjaként előálló ENSEMBLE modell Budapestre vonatkozó előrejelzéseit a 20182019-es fútési szezonra vizsgáltuk. Az elörejelzett légszennyező anyagok közül a kisméretü részecskék $\left(\mathrm{PM}_{2,5}\right.$ és $\left.\mathrm{PM}_{10}\right)$ koncentrációit elemeztük, melyből jelen tanulmányban az optimalizált $\mathrm{PM}_{2,5}$ elörejelzést mutatjuk be.

A modellek a budapesti mérőpontokra - a SILAM modell kivételével - egyértelmü alulbecslést mutattak a téli félévben, ezért célul tüztük ki egy olyan előrejelzés előállítását, amely a városi mérőpontokra pontosabb előrejelzést ad az egyes modellek előrejelzéseinek, illetve a korábbi mérések adatainak felhasználásával.

A Sofiev et al. (2017) alapján, általunk optimalizált előrejelzést az egyes modellek előrejelzéseit értékelve, azok lineáris kombinációjaként adtuk meg. A modelleket különböző súllyal vettünk figyelembe, illetve ehhez hozzáadtunk egy konstans tagot. Ezeket az együtthatókat az adott napi előrejelzéshez az azt megelőző tíznapos tanulási időszak adatait használva választottunk meg az alapján, hogy hogyan teljesítettek az egyes modellek az adott időtartam során (Varga-Balogh et al., 2020).

$\mathrm{Az}$ OLM rendszerében Budapesten hat állomáson érhető el $\mathrm{PM}_{2,5}$ mérés, ezért ezeken az állomásokon vizsgáltuk az előrejelzések beválását. Az előrejelzések átlagos négyzetes hibája a 2. ábrán látható. A színes görbék a CAMS modelleket, a feketével jelölt görbe pedig az ezek lineáris kombinációjaként előálló optimalizált modell átlagos négyzetes hibáját (RMSE) mutatja a 2018. október 15. és 2019. április 15. közti fütési szezon során. A szennyezett időszakokat a grafikon alján lévő szürke sávok jelzik. Jól látható, hogy a szennyezett időszakok során az optimalizált modell az egyes modelleknél pontosabb előrejelzést adott (kisebb RMSE), azonban az ezt követő időszak során jóval nagyobb hibával volt terhelt. Ez azzal magyarázható, hogy a légszennyezettség a tél során beálló stabil helyzet során fokozatosan növekszik, majd jellemzően egy hidegfrontnak köszönhetően hirtelen kitisztul, így a tanulási időszak során az optimalizálás a modelleket magasabb értékek felé korrigálja, a hirtelen csökkenést azonban csak több nap után tudja lekövetni.

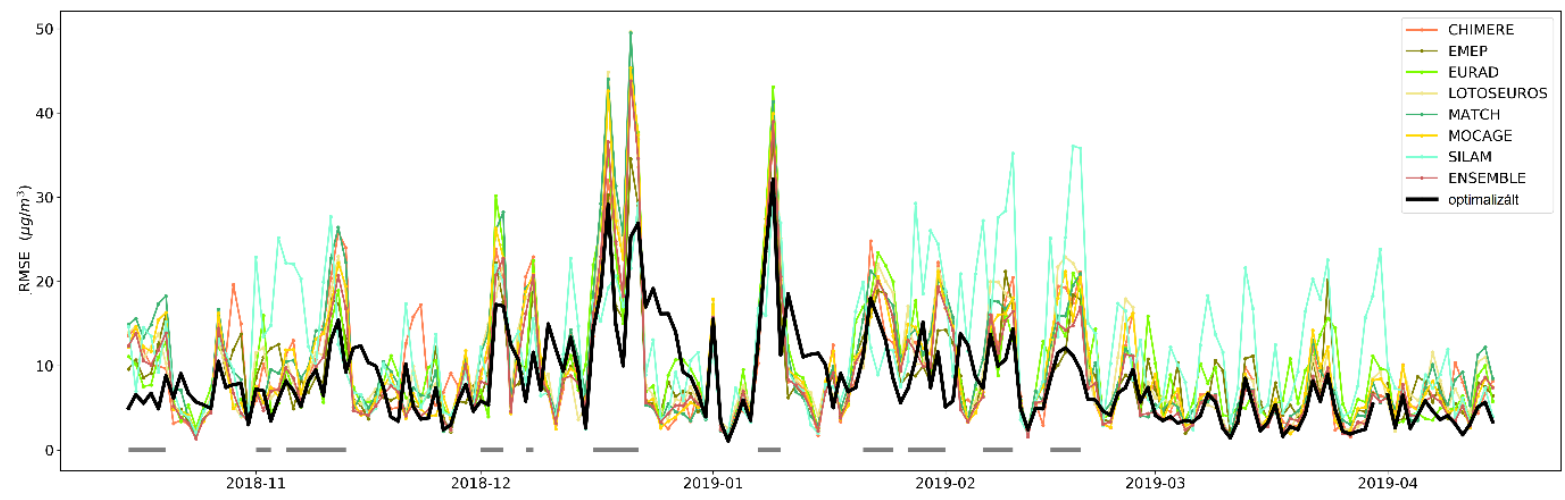

2. ábra: A CAMS modellek elörejelzésének (színessel), és az optimalizált előrejelzés (feketével) átlagos négyzetes hibája a 2018-2019-es fütési szezon során (Varga-Balogh et al., 2020). 
Az optimalizált elörejelzés hibáját jelentősen csökkentette a lineáris kombináció konstans tagja, ezért a modellekből - egy szintén 10 napos időszakot használva - elkészítettük annak BIAS-korrigált párját is, melyet a 10 napos időszak alatt mért átlagos hibával eltolva kaptunk meg. Ezekből, illetve az eredeti modellekből is előállítottunk a korábbi módszer alapján az optimalizált előrejelzéseket. A 3. ábrán a CAMS ENSEMBLE, ennek BIAS-korrigált párja, valamint a kétféle módon előállított optimalizált elörejelzések, illetve a mérések idősora látható három budapesti mérőállomásra.
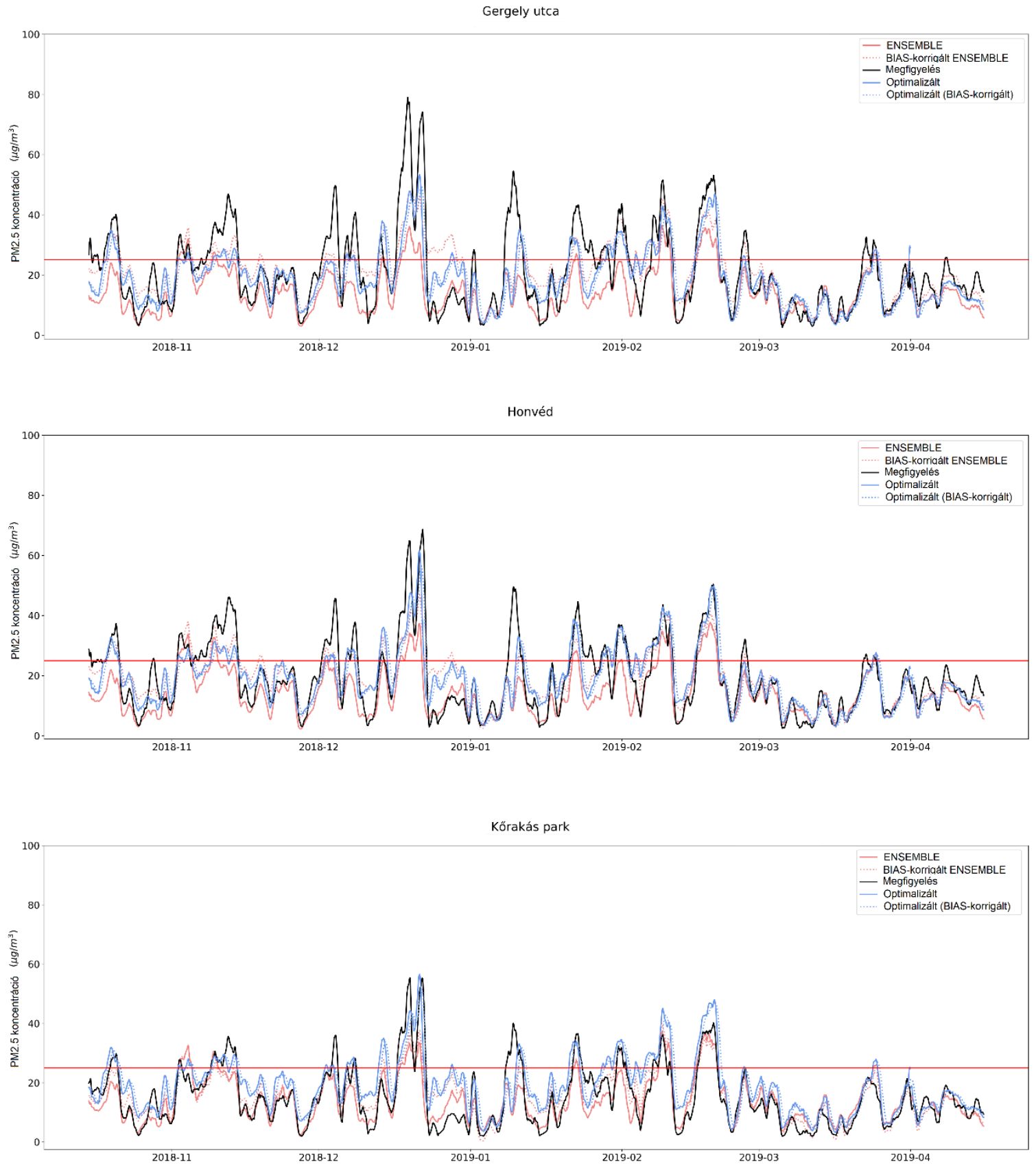

3. ábra: A nyers (piros folytonos), és a 10 napos időszak során BIAS-korrigált CAMS

ENSEMBLE (piros szaggatott) $\mathrm{PM}_{2,5}$ előrejelzései, illetve a nyers (kék folytonos) és korrigált modellekből elkészült (kék szaggatott) optimalizált előrejelzések, valamint az adott állomáson mért $\mathrm{PM}_{2,5}$ koncentráció idősorai három budapesti állomásra. A vízszintes piros vonal az Egészségügyi Világszervezet (WHO) által megállapított $25 \mu \mathrm{g} / \mathrm{m}^{3}$ határértéket mutatja (Varga-Balogh et al., 2020). 
Mindhárom állomáson megfigyelhetjük, hogy az optimalizált elörejelzések a magasabb koncentrációk esetén pontosabbak, azonban az ezt követő hirtelen bekövetkezö tisztuláskor az ENSEMBLE előrejelzés bizonyul jobbnak. A BIAS-korrigálás a szmogos időszakok során javította a CAMS ENSEMBLE előrejelzését, azonban a 10 napos időszak hosszúsága miatt a látványos és gyors csökkenést követően a korrigált ENSEMBLE elörejelzés is felülbecsülte a tényleges értékeket.

Az előrejelzések pontosítása érdekében célszerü lenne rövidebb tanulási időszakot választani a BIAS-korrigáláshoz, valamint az optimalizáláshoz is, azonban az idősorban előforduló gyakori adathiány egyelöre ezt nem teszi lehetővé.

\section{Légszennyezettség 2020 tavaszán}

2020 év elején a COVID-19 világjárvány hatására világszerte korlátozó intézkedéseket vezettek be. Rengeteg gyár bezárt, illetve ahol lehetett, ott a cégek otthoni munkavégzésre álltak át. Mind a nemzetközi, mind pedig a belföldi utazás mennyisége jelentősen csökkent, így a repülőgépes és az autóforgalom is mérséklődött. A légi közlekedés drasztikus visszaesésével jelentős csökkenést mutatott a teljes légoszlopra vonatkozó troposzférikus $\mathrm{NO}_{2}$ mennyisége, de a felszíni koncentrációk is sok helyen mutattak alacsonyabb értékeket a korábbiaknál (Menut et al., 2020).

A látványos nemzetközi példák után arra a kérdésre kerestük a választ, hogy hogyan alakult Magyarországon a légszennyező anyagok koncentrációja 2020 első felében. A hazai felszíni mérési értékek az OLM adataiból állnak rendelkezésre.

A 4. ábrán nitrogén-oxid $\left(\mathrm{NO}_{\mathrm{x}}\right)$ koncentrációjának menete látható a belvárosi Széna téri állomáson 2020-ra illetve a korábbi évek ugyanazon időszakára. Az ábrán a piros sáv jelöli a kijárási korlátozás időszakát, a veszélyhelyzet ezt megelőző időtartamát lilával, az ezt követőt pedig zölddel jelöltük.

Ezen a belvárosi állomás adatain az látható, az elrendelt időszakok ideje alatt a korábbi éveknél alacsonyabb $\mathrm{NO}_{\mathrm{x}}$ koncentrációt mértek, azonban az is látható, hogy ez már a februári időszakra is jellemző volt a 2020 -as évben.

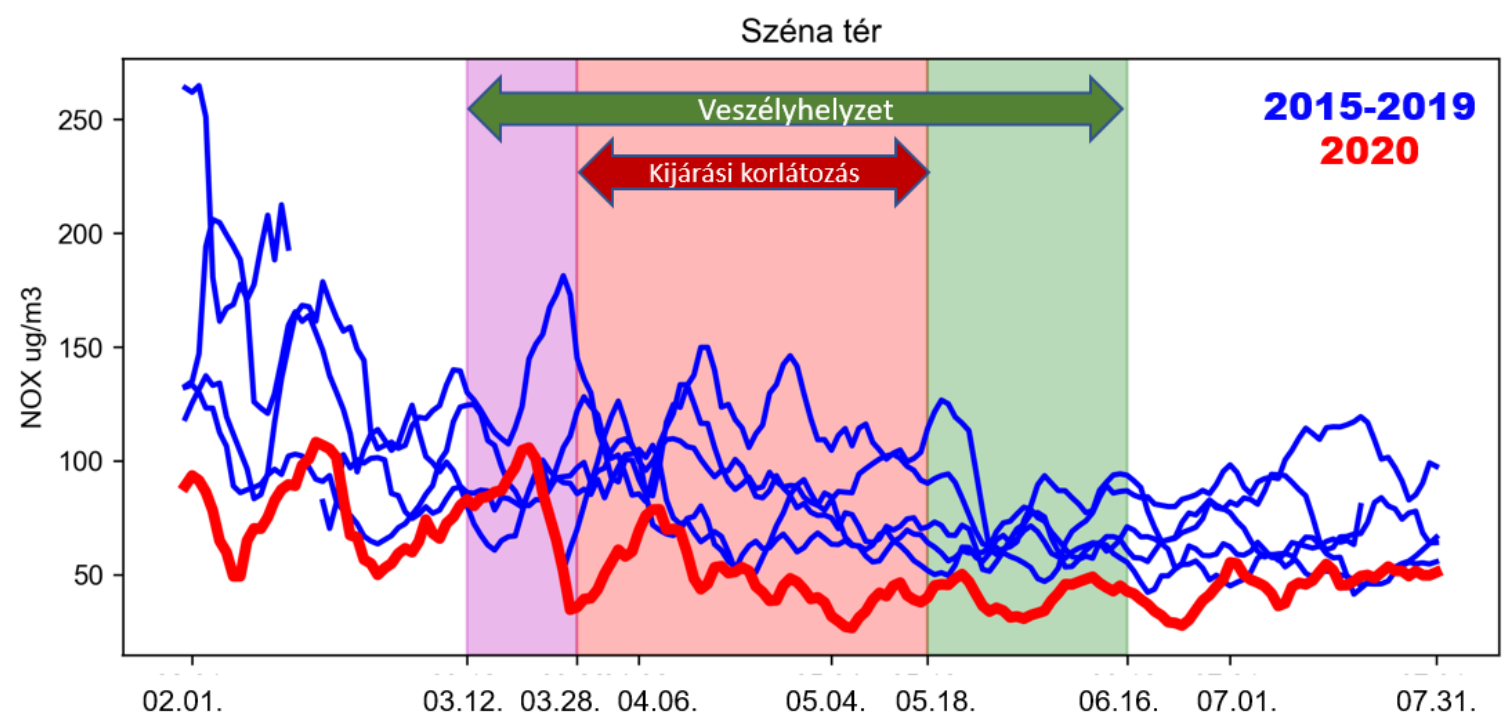

4. ábra: A napi átlagos $\mathrm{NO}_{\mathrm{x}}$-koncentráció alakulása a Széna téren februártól júliusig 2015-től 2020-ig. 
Az 5. ábrán a napi átlagos ózonkoncentráció látható a csepeli mérőállomáson 2015-2020 februárjától júliusig. Ezen az állomáson a korábbi évekhez képes látványosan magasabb ózonkoncentrációt láthatunk a korlátozások időszaka alatt, mely a légköri reakciók mellett nagyrészt annak tudható be, hogy a 2020 áprilisa kifejezetten napos, száraz időszak volt.

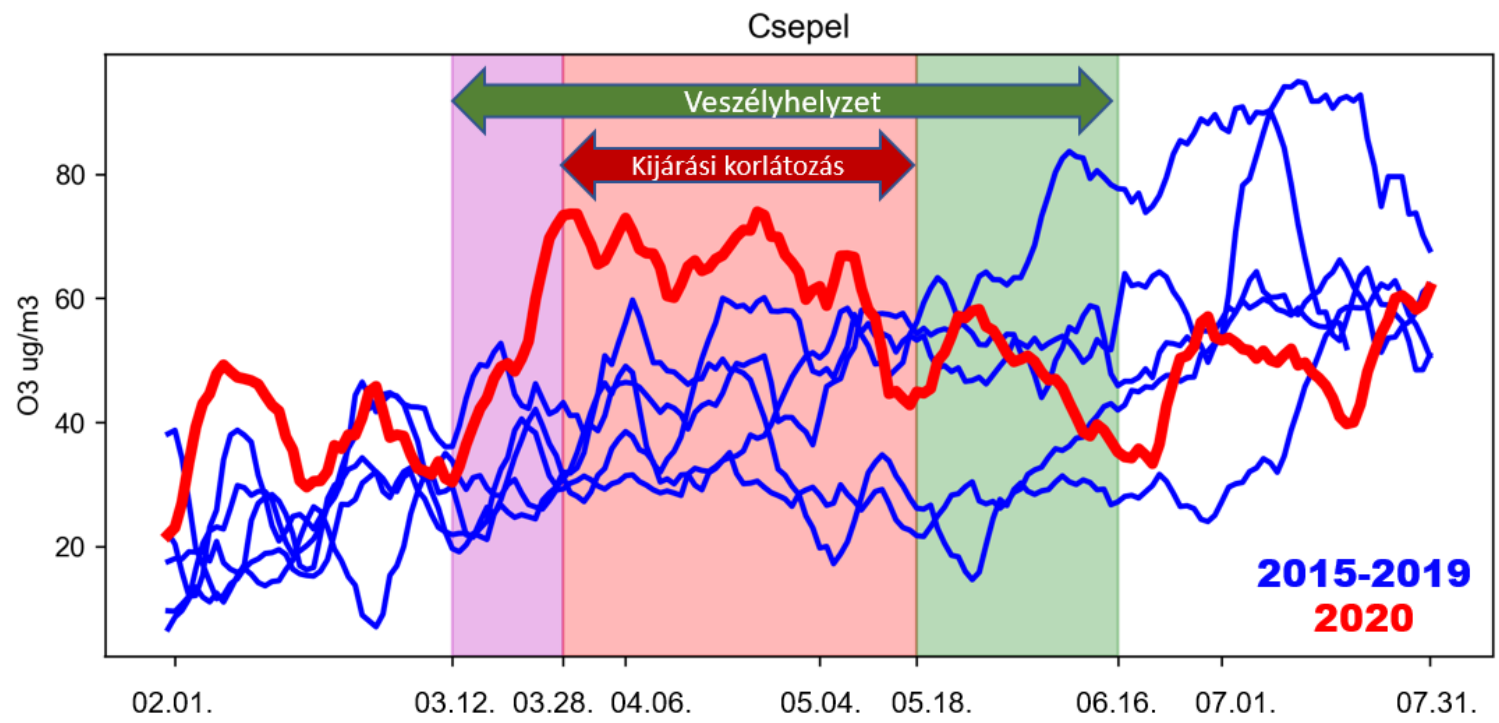

5. ábra: Az ózonkoncentráció napi átlagai a csepeli állomáson 2020 februárja és júliusa között, valamint a 2015-2019 évek azonos időszakai.

A példaként kiemelt állomásokon a többi mérési ponthoz képest nagyobb eltérést tapasztaltunk. Fontos azonban kiemelni, hogy az egyes állomásokon mért koncentrációkat a kibocsátás változásai mellett a meteorológiai viszonyok is jelentősen befolyásolják, így ezek az értékek a két hatás együtteseként álltak elő (Salma et al., 2020).

\section{Köszönetnyilvánítás}

A kutatásokat a Nemzeti Kutatási, Fejlesztési és Innovációs Alap K-128805, és K-128818 pályázatai támogatták.

\section{Hivatkozások}

Menut, L., Bessagnet, B., Mailler, G.S.S., Pennel, R., Cholakian, A., 2020: Impact of lockdown measures to combat Covid-19 on air quality over western Europe. Science of The Total Environment, 741: 140426 https://doi.org/10.1016/j.scitotenv.2020.140426

Salma, I., Vörösmarty, M., Gyöngyösi, A.Z., Thén, W., Weidinger, T.: What can we learn about urban air quality with regard to the first outbreak of the COVID-19 pandemic? A case study from Central Europe. Atmos. Chem. Phys. Discuss., https://doi.org/10.5194/acp-2020-997, in review, 2020.

Sofiev, M.; Ritenberga, O.; Albertini, R.; Arteta, J.; Belmonte, J.; Bernstein, C.G.; Bonini, M.; Celenk, S.; Damialis, A.; Douros, J.; et al. 2017: Multi-model ensemble simulations of olive pollen distribution in Europe in 2014: Current status and outlook. Atmos. Chem. Phys., 17: 12341-12360. https://doi.org/10.5194/acp-17-12341-2017 
Varga-Balogh, A., Leelössy, Á., Lagzi, I.L., Mészáros, R., 2020: Time-dependent downscaling of PM2.5 predictions from CAMS air quality models to urban 2 monitoring sites in Budapest. Atmosphere, 11(6): 669. https://doi.org/10.3390/atmos11060669

\section{ORCID}

Varga-Balogh A. (D) https://orcid.org/0000-0002-5210-5854

Leelössy Á. (D) https://orcid.org/0000-0001-9583-0127

Mészáros $R$. iD https://orcid.org/0000-0002-0550-9266 